\title{
Ascitic eruption in an umbilical hernia in cirrhosis
}

\author{
Alexandre Oliveira Ferreira, Rui Tato Marinho, Fernando Ramalho, José Velosa
}

Department of

Gastroenterology and Hepatology, Medical School of Lisbon, Hospital Santa Maria, Lisbon, Portugal

\section{Correspondence to}

Dr Alexandre Oliveira Ferreira, alex.fsof@gmail.com
To cite: Ferreira $\mathrm{AO}$ Marinho RT, Ramalho F, et al. BMJ Case Reports Published online: 2 January 2013 doi:10.1136/bcr-2012007741

\section{DESCRIPTION}

A male patient in his mid-30s with end stage alcoholic cirrhosis (Child-Pugh C, MELD 21) was referred to our hospital due to refractory ascites. He had had several hospital admissions for spontaneous bacterial peritonitis, encephalopathy and sepsis. He was submitted to an emergency herniorraphy due to a strangulated umbilical hernia. Suddenly the surgical suture did not hold the intra-abdominal pressure and the ascitic fluid erupted through the surgical suture in a fountainlike way (figure 1). The patient died a few days later.

\section{Learning points}

Umbilical hernias are very common in cirrhotic patients, and their management carries several challenges. One should be aware that:

- Early repair is safer than it was in the past and can be considered for selected patients, preferably Child A status.

- In those with refractory ascites consideration of a transjugular intrahepatic portosystemic shunt before the elective herniorraphy ${ }^{1}$ is a valid option with potential to avoid the morbidity and mortality associated with repair in the emergency setting.

- Uncontrolled ascites appears to be strongly predictive of hernia recurrence ${ }^{2}$ but a permanent mesh can be used in complicated hernias in cirrhotic patients, with minimal wound-related morbidity and a significantly lower rate of recurrence. ${ }^{3}$

- Urgent repair of umbilical hernia in cirrhotic patients is only indicated when serious complications develop, such as a strangulated hernia or rupture, bearing in mind that in these particular cases great care should be held to control the ascites in the perioperative period to prevent complications such as leakage, eruption (as in our case) or recurrence of the hernia.

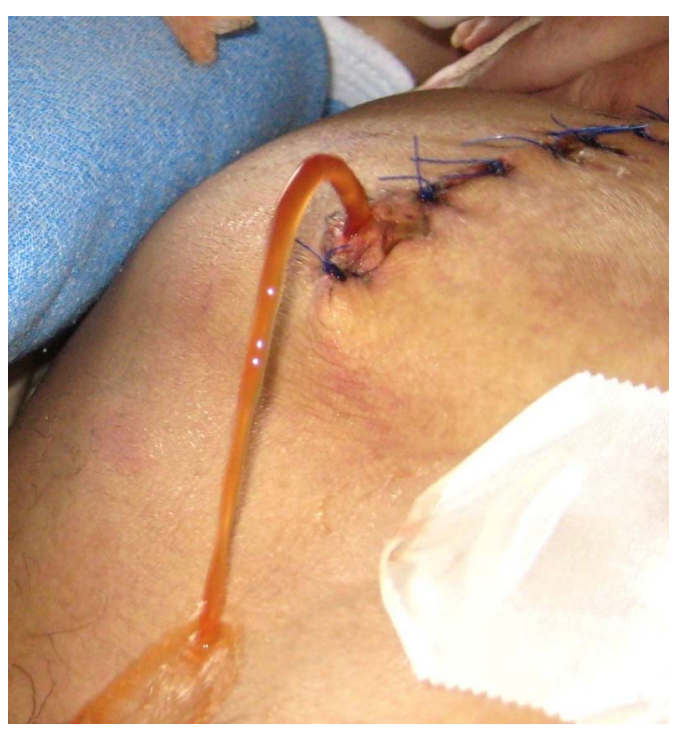

Figure 1 Fountain-like eruption of ascitic fluid through the suture dehiscence.

Competing interests None.

Patient consent Obtained.

Provenance and peer review Not commissioned; externally peer reviewed.

\section{REFERENCES}

1 Triantos CK, Kehagias I, Nikolopoulou V, et al. Surgical repair of umbilical hernias in cirrhosis with ascites. Am J Med Sci 2011;341:222-6.

2 McKay A, Dixon E, Bathe O, et al. Umbilical hernia repair in the presence of cirrhosis and ascites: results of a survey and review of the literature. Hernia 2009;13:461-8.

3 Ammar SA. Management of complicated umbilical hernias in cirrhotic patients using permanent mesh: randomized clinical trial. Hernia 2010;14:35-8. 
Copyright 2013 BMJ Publishing Group. All rights reserved. For permission to reuse any of this content visit http://group.bmj.com/group/rights-licensing/permissions.

BMJ Case Report Fellows may re-use this article for personal use and teaching without any further permission.

Become a Fellow of BMJ Case Reports today and you can:

- Submit as many cases as you like

- Enjoy fast sympathetic peer review and rapid publication of accepted articles

- Access all the published articles

- Re-use any of the published material for personal use and teaching without further permission

For information on Institutional Fellowships contact consortiasales@bmjgroup.com

Visit casereports.bmj.com for more articles like this and to become a Fellow 